\title{
Amenities and the Labor Earnings Function
}

\author{
PHILIP E. GRAVES \\ University of Colorado, Boulder, CO 80309 \\ MICHELLE M. ARTHUR \\ University of Illinois, Urbana-Champaign, IL 61820 \\ ROBERT L. SEXTON \\ Pepperdine University, Malibu, CA 90263
}

Desirable locations are, other things equal, expected to be characterized by a mix of higher rents or lower wages. That is, if one area is more attractive than others, inmigration would occur, driving up the demand for land (hence raising rents) and increasing the supply of labor (hence lowering wages). The in-movement will continue until utility is the same across locations in equilibrium. Failing to hold constant amenities in the traditional earnings functions employed by labor economists will result, then, in omitted-variable bias if worker characteristics (years of schooling, union membership, and so on) are correlated with amenities. By way of illustration, our empirical analysis suggests that as much as 50 percent of the apparent return to unionization may be due to the impact of undesirable amenities, resulting in compensating higher wages, in areas of union strength - unionization is being credited with wage gains that properly should be attributed to climate and other (dis)amenities. Similar, though smaller, effects on other coefficients of the earnings function variables are presented.

\section{Introduction}

In economic models, variations in rents and wages are typically viewed as compensating in nature; that is, competitive bidding in land and labor markets results in compensation for desirable and undesirable amenities that vary over space (Blomquist, 1988, hereinafter BBH; Haurin, 1980; Roback, 1982; Rosen, 1979). Amenities may be either firm-specific (e.g., access to mine-mouths) or household-specific (e.g., scenic views) or may affect both firms and households (e.g., a deepwater port attractive to both). The implications for equilibrium wages and rents relative to neutral locations are that purely firm amenities result in both higher wages and higher rents, while purely household amenities yield lower wages and higher rents in some mix. As Roback (1988, p. 23) concludes, "Regional differences in amenities can account for wage differences; in contrast, cost of living variations do not account for wage differences, but actually exacerbate them." 
Usually, however, the earnings functions employed by labor economists to gain insights into returns to education, experience, union membership, benefits of marriage, occupational status, and so on do not explicitly incorporate wage impacts of amenity variation. ${ }^{1}$ Yet many worker characteristics, such as years of schooling or union membership, are likely to be correlated with amenities with resulting omitted-variable bias in the coefficients of earnings function variables.

Section II provides a theoretical backdrop for the empirical results presented in Section III which contrasts results for traditional earnings functions with two alternative variants that are more properly specified. Section IV summarizes our findings and offers recommendations for future work.

\section{Theoretical Background}

There are now many published formal expositions of the equilibrium joint job-andresidence location decision (BBH, 1998). The following informal and brief exposition is made useful, as will become clear, by some anomalies that exist in many typical data sets, including our own.

The equilibrium view is that "other things equal" a household in a location with higher rents must receive higher wages - hence spatial equalization of utility implies that indirect utility functions in wage-rent space must be upward-sloping. Similarly, "other things equal," firms in high-rent locations must be compensated with lower wages, if unit costs are to be equal in all locations producing a traded good selling at a ubiquitous national price; hence the unit cost function must be downward-sloping. The intersection of these two curves would, in a "featureless" world, give rise to the unique wagerent combination that is consistent with zero spatial variation in both profits and utility.

"Other things" may be unequal, however, in various combinations of two general ways. First, a location may be abnormally desirable to a household (possessing, say, an especially hospitable climate), without any direct firm impacts at the ubiquitous wagerent combination - in this case, equilibrium requires that wages will be lower and rents higher in some combination (Figure 1a). This results from households' relocating to consume the desirable and (unpriced) amenity, increasing both the supply of labor and demand for housing. The higher rents in this case are a measure (along with the lower wages) of the "benefits of living" in the desirable location and are not appropriately viewed as a higher cost of living.

Second, a location may be abnormally desirable to a firm (possessing, say, access to a mine-mouth or agglomeration economies due to proximity to other firms), ignoring any household impacts at the prevalent wage-rent combination - in this case, equilibrium requires that wages and rents both be higher in some combination (Figure $1 b$ ). This results from firms relocating to the profitable area, driving up demands for both labor and land. Note that in this case households paying higher rents require - and receive, as shown in Figure $1 \mathrm{~b}$ - equilibrium compensation in labor markets. Hence, higher rents here do represent a higher "cost of living" but wage compensation automatically occurs. 
Figure 1

Amenity Impacts on Wages and Rents: Pure Cases

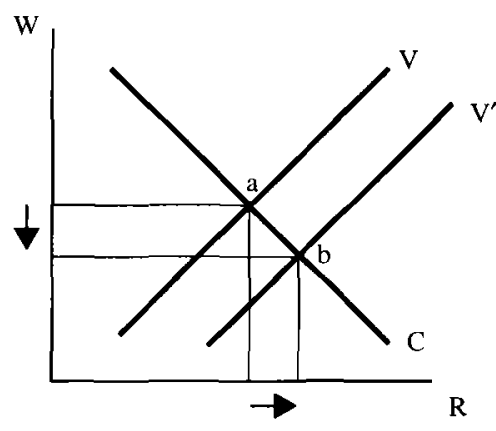

Pure Household Amenity Case

(a)

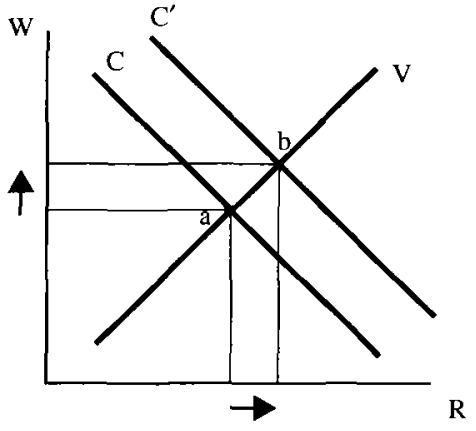

Pure Firm Amenity Case

(b)

Of course any particular amenity might affect both household utility and firm profitability (for example, a deepwater port might be an attractive amenity to both households and firms, as in San Francisco or Seattle). In this case, rents would be higher with an ambiguous wage effect depending on whether the amenity is more important to firms or to households. Should an amenity be desirable to households and undesirable to firms (say, cleaner air that results from costly controls being imposed on local firms), wages would clearly be lower - since the supply of labor would be larger while the labor demand would be lower - but the impact on rents would be ambiguous.

The preceding more general cases are critical to understanding how amenities should affect estimated parameters of the earnings function. Considering the return to education, one might a priori expect that failing to control for amenities would result in an understatement of the return to education because locations offering desirable amenities that are normal goods (Graves, 1979) will become disproportionately occupied by those with high incomes, typically those with high education. The increase in the supply of labor of the high-skilled in desirable areas would be expected to drive down wages (as in Figure 1a) - hence, real earnings are higher than the measured nominal earnings employed in the earnings function. Essentially, the worker takes a portion of his or her wages in the form of higher amenities; this portion is unobserved, with nominal wages understating real wages.

But, real world locations are more complex. In many studies, including here, only relatively populous areas (SMSAs or larger counties) are observed due to data limitations. However, such large locations tend as an empirical matter to be relatively more desirable from a firm perspective than from a household perspective. Figure 2 shows that were the amenity only of value to the households, the compensation would be 
Figure 2

\section{The Case of an Amenity Having Greater Value to Firms than to Households}

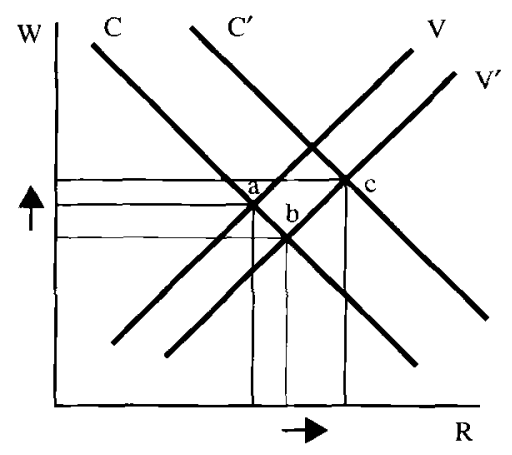

reflected in the move from a to $b$. But, due to the large value of the amenity to firms, actual compensation moves from $b$ to $c$, because much of the observed rent increase must be compensated for by higher wages, i.e., it represents a higher "cost of living."

This distinction matters greatly: In the $\mathrm{BBH}$ data that we employ, wage and rent compensation are seen to have a correlation of -0.75 . If the world were as depicted in Figure la, we would expect a large positive correlation between these variables (since compensation in labor markets is the negative of the move shown in Figure la). Similarly, while wage compensation is highly positively correlated with overall desirability of a location, rent compensation is only correlated 0.07 with overall desirability. Since large, desirable locations have high median gross rents relative to rent compensation for amenities, much compensation is required in the labor market in equilibrium (Figure 2 ). Hence, the return to education is actually lower than one would have initially expected (thinking in terms of Figure 1a), since for our analysis - and probably many other studies — the situation is as depicted in Figure 2.

\section{Empirical Results}

Our data are the 246 counties underlying the BBH study. ${ }^{2}$ The wage and rent compensation variables for those counties are merged with additional county-specific economic and sociodemographic information from four sources. ${ }^{3}$ Table 1 presents the variable definitions and summary statistics for all our variables. For ease of comparison with other studies and to eliminate aggregation difficulties, we analyze only male eamings with independent variables generally specific to that group.

Column (1) of Table 2 presents the traditional log-linear earnings function. ${ }^{4}$ The fit is good and variable impacts are as generally reported (though percent white, while insignificant, has a negative $\operatorname{sign}^{5}$ ). Columns (2) through (4) introduce amenity and 
Table 1

Summary Statistics

\begin{tabular}{lrc}
\hline Variable & Mean & Standard Deviation \\
\hline Median Income (\$) - MY & 18,131 & 2,614 \\
Education (yrs) - Educ & 12.568 & 0.4447 \\
Experience (yrs) - Exper & 9.9650 & 2.8928 \\
Union (=1) & 0.2275 & 0.0842 \\
Urban (\%) & 0.8315 & 0.1342 \\
White (\%) & 0.8872 & 0.0920 \\
Married (\%) & 0.6030 & 0.0655 \\
Total Population - Totpop & 453,586 & 669,315 \\
Manufacturing (\%) - Mfg & 0.2702 & 0.1136 \\
Agriculture, Farm, Forest (\%) - Agfm & 0.0373 & 0.0411 \\
Construction (\%) - Con & 0.0930 & 0.0302 \\
Transportation (\%) - Transport & 0.0958 & 0.0267 \\
Wholesale, Retail, Trade (\%) - Whret & 0.1994 & 0.0278 \\
Services (\%) & 0.2014 & 0.0536 \\
Professional (\%) & 0.1025 & 0.2900 \\
Northeast (=1) - Dnorthe & 0.2602 & 0.4396 \\
South (=1) - Dsouth & 0.1504 & 0.3582 \\
West (=1) - Dwest & 0.3008 & 0.4595 \\
Wage Compensation (\$) — Wcontp & $1,036.156$ & 997.376 \\
Rent Compensation (\$) & -855.992 & 799.115 \\
Sum of Amenities (\$) & 180.164 & 656.268 \\
\hline
\end{tabular}

regional dummy variables as independent controls; the notion is that one wishes to know the impacts of the traditional variables holding constant amenity wage compensation. A plausible alternative approach, shown in Columns (5) and (6), is to adjust the dependent earnings variable by adding to it amenity wage compensation. This adjustment directly offsets the fact that high-amenity locations have lower wages by adding back what is paid (or received, in the case of undesirable locations) in labor markets for amenities to obtain an amenity-neutral earnings variable. As will become clear, results are robust to alternative approaches and are somewhat more dramatic for the latter.

Consider first comparison of the traditional earnings function, Column (1), with Columns (2)-(4) which hold wage compensation and regional effects constant. As expected from the theoretical discussion of Section II, holding constant household 
Table 2

Earnings Function Estimates

\begin{tabular}{|c|c|c|c|c|c|c|}
\hline Variables & $\mathrm{L}^{\mathrm{d}} M Y$ & $\mathrm{~L} M Y$ & $\mathrm{~L} M Y$ & $\mathrm{~L} M Y$ & $\operatorname{adjL} M Y$ & $\operatorname{adjL} M Y$ \\
\hline Educ & $\begin{array}{l}0.1895^{\mathrm{a}} \\
(12.56)\end{array}$ & $\begin{array}{l}0.1737^{\mathrm{a}} \\
(11.74)\end{array}$ & $\begin{array}{l}0.1782^{\mathrm{a}} \\
(11.87)\end{array}$ & $\begin{array}{c}0.1649^{a} \\
(11.25)\end{array}$ & $\begin{array}{c}0.1515^{\mathrm{a}} \\
(10.83)\end{array}$ & $\begin{array}{l}0.1452^{\mathrm{a}} \\
(10.43)\end{array}$ \\
\hline Exper & $\begin{array}{l}0.0198^{\mathrm{a}} \\
(2.61)\end{array}$ & $\begin{array}{l}0.0158^{\mathrm{b}} \\
(2.16)\end{array}$ & $\begin{array}{l}0.0287^{\mathrm{a}} \\
(3.71)\end{array}$ & $\begin{array}{l}0.0247^{\mathrm{a}} \\
(3.31)\end{array}$ & $\begin{array}{l}0.0117^{\mathrm{c}} \\
(1.66)\end{array}$ & $\begin{array}{l}0.0202^{\mathrm{a}} \\
(2.82)\end{array}$ \\
\hline Expersq & $\begin{array}{l}-0.0009^{\mathrm{a}} \\
(3.18)\end{array}$ & $\begin{array}{l}-0.0007^{\mathrm{b}} \\
(2.52)\end{array}$ & $\begin{array}{l}-0.0011^{\mathrm{a}} \\
(3.78)\end{array}$ & $\begin{array}{l}-0.0009^{\mathrm{a}} \\
(3.21)\end{array}$ & $\begin{array}{l}-0.0005 \\
(1.84)\end{array}$ & $\begin{array}{l}-0.0007^{a} \\
(2.58)\end{array}$ \\
\hline Union & $\begin{array}{l}0.8111^{\mathrm{a}} \\
(8.38)\end{array}$ & $\begin{array}{l}0.5999^{\mathrm{a}} \\
(5.85)\end{array}$ & $\begin{array}{l}0.7715^{\mathrm{a}} \\
(7.33)\end{array}$ & $\begin{array}{l}0.5972^{\mathrm{a}} \\
(5.55)\end{array}$ & $\begin{array}{l}0.4093^{\mathrm{a}} \\
(4.56)\end{array}$ & $\begin{array}{l}0.4387^{a} \\
(4.50)\end{array}$ \\
\hline Urban & $\begin{array}{l}0.3327^{\mathrm{a}} \\
(5.92)\end{array}$ & $\begin{array}{l}0.3197^{\mathrm{a}} \\
(5.94)\end{array}$ & $\begin{array}{l}0.3006^{\mathrm{a}} \\
(5.29)\end{array}$ & $\begin{array}{l}0.3126^{\mathrm{a}} \\
(5.73)\end{array}$ & $\begin{array}{l}0.2867^{\mathrm{a}} \\
(5.50)\end{array}$ & $\begin{array}{l}0.2995^{\mathrm{a}} \\
(5.68)\end{array}$ \\
\hline White & $\begin{array}{l}-0.1389 \\
(1.41)\end{array}$ & $\begin{array}{l}-0.0735 \\
(0.77)\end{array}$ & $\begin{array}{l}-0.1429 \\
(1.46)\end{array}$ & $\begin{array}{l}-0.0473 \\
(0.49)\end{array}$ & $\begin{array}{l}-0.0209 \\
(0.23)\end{array}$ & $\begin{array}{l}0.0278 \\
(0.31)\end{array}$ \\
\hline Married & $\begin{array}{l}0.7892^{\mathrm{a}} \\
(5.74)\end{array}$ & $\begin{array}{l}0.7285^{a} \\
(5.52)\end{array}$ & $\begin{array}{l}0.7659^{a} \\
(5.73)\end{array}$ & $\begin{array}{l}0.7092^{\mathrm{a}} \\
(5.52)\end{array}$ & $\begin{array}{l}0.6386^{\mathrm{a}} \\
(5.01)\end{array}$ & $\begin{array}{l}0.6240^{\mathrm{a}} \\
(5.04)\end{array}$ \\
\hline Totpop & $\begin{array}{l}1.2 \times 10^{-8} \\
(1.30)\end{array}$ & $\begin{array}{l}5.7 \times 10^{-9} \\
(0.64)\end{array}$ & $\begin{array}{l}1.0 \times 10^{-9} \\
(1.13)\end{array}$ & $\begin{array}{l}6.3 \times 10^{-9} \\
(0.72)\end{array}$ & $\begin{array}{l}1.1 \times 10^{-9} \\
(0.13)\end{array}$ & $\begin{array}{l}3.5 \times 10^{-9} \\
(0.41)\end{array}$ \\
\hline$M f g$ & $\begin{array}{l}0.3731^{\mathrm{b}} \\
(2.46)\end{array}$ & $\begin{array}{l}0.3180^{\mathrm{b}} \\
(2.19)\end{array}$ & $\begin{array}{l}0.1757 \\
(1.11)\end{array}$ & $\begin{array}{l}0.1103 \\
(0.72)\end{array}$ & $\begin{array}{l}0.2648 \\
(1.88)\end{array}$ & $\begin{array}{l}0.0575 \\
(0.39)\end{array}$ \\
\hline Agfm & $\begin{array}{l}0.5118^{\mathrm{h}} \\
(2.52)\end{array}$ & $\begin{array}{l}0.4779^{b} \\
(2.46)\end{array}$ & $\begin{array}{l}0.2871 \\
(1.32)\end{array}$ & $\begin{array}{l}0.3192 \\
(1.58)\end{array}$ & $\begin{array}{l}0.4070^{\mathrm{b}} \\
(2.16)\end{array}$ & $\begin{array}{l}0.3117 \\
(1.59)\end{array}$ \\
\hline Con & $\begin{array}{l}0.664 \mathrm{I}^{\mathrm{b}} \\
(2.28)\end{array}$ & $\begin{array}{l}0.5938^{b} \\
(2.13)\end{array}$ & $\begin{array}{l}0.5380 \\
(1.82)\end{array}$ & $\begin{array}{l}0.5351 \\
(1.89)\end{array}$ & $\begin{array}{l}0.5307^{\mathrm{h}} \\
(1.96)\end{array}$ & $\begin{array}{l}0.5235 \\
(1.91)\end{array}$ \\
\hline Transport & $\begin{array}{l}0.4527 \\
(1.61)\end{array}$ & $\begin{array}{l}0.4248 \\
(1.58)\end{array}$ & $\begin{array}{l}0.3263 \\
(1.15)\end{array}$ & $\begin{array}{l}0.2527 \\
(0.93)\end{array}$ & $\begin{array}{l}0.3515 \\
(1.35)\end{array}$ & $\begin{array}{l}0.1488 \\
(0.57)\end{array}$ \\
\hline Whret & $\begin{array}{l}-0.6263^{h} \\
(2.05)\end{array}$ & $\begin{array}{l}-0.7258^{\mathrm{h}} \\
(2.48)\end{array}$ & $\begin{array}{l}-0.902 l^{4} \\
(2.92)\end{array}$ & $\begin{array}{l}-1.0195^{\mathrm{a}} \\
(3.43)\end{array}$ & $\begin{array}{l}-0.7296^{\mathrm{a}} \\
(2.58)\end{array}$ & $\begin{array}{l}-1.0259^{\mathrm{a}} \\
(3.58)\end{array}$ \\
\hline Services & $\begin{array}{l}0.1279 \\
(0.54)\end{array}$ & $\begin{array}{l}0.1284 \\
(0.57)\end{array}$ & $\begin{array}{l}0.0449 \\
(0.19)\end{array}$ & $\begin{array}{c}0.0390 \\
(0.17)\end{array}$ & $\begin{array}{l}0.1273 \\
(0.58)\end{array}$ & $\begin{array}{l}0.0352 \\
(0.16)\end{array}$ \\
\hline Dnortheast & & & $\begin{array}{l}-0.0715^{\mathrm{u}} \\
(3.97)\end{array}$ & $\begin{array}{l}-0.0686^{11} \\
(3.98)\end{array}$ & & $\begin{array}{l}-0.0632^{\mathrm{a}} \\
(3.79)\end{array}$ \\
\hline Dsouth & & & $\begin{array}{l}-0.0415 \\
(1.84)\end{array}$ & $\begin{array}{l}-0.0198 \\
(0.90)\end{array}$ & & $\begin{array}{l}-0.0011 \\
(0.05)\end{array}$ \\
\hline Dwest & & & $\begin{array}{l}-0.0197 \\
(1.08)\end{array}$ & $\begin{array}{l}-0.0295 \\
(1.68)\end{array}$ & & $\begin{array}{l}-0.0349^{b} \\
(2.06)\end{array}$ \\
\hline Wcomp & & $\begin{array}{l}-3.2 \times 10^{-5 a} \\
(4.77)\end{array}$ & & $\begin{array}{l}-3.2 \times 10^{-5 a} \\
(4.64)\end{array}$ & & \\
\hline $\operatorname{Adj} R^{2}$ & 0.679 & 0.707 & 0.698 & 0.723 & 0.564 & 0.590 \\
\hline SSE & 1.62 & 1.47 & 1.50 & 1.37 & 1.39 & 1.29 \\
\hline
\end{tabular}

Notes: a, h.c coefficients are significantly different from zero at 1,5 , and $10 \%$ levels of confidence, respectively, two-tail test. $t$-statistics are in parentheses. $\mathrm{L}$ indicates the natural logarithm of the respective dependent variable. 
amenity variation reveals a smaller return to education than would be inferred from the traditional earnings function. This reduction, a bit over an 8 percent decline, is largely independent of regional effects which also reveal lower returns to education, ceteris paribus. One possible interpretation of the regional dummies, since occupational categories are held constant, is that they reflect additional amenities not captured in the BBH data; under this view incorporation of amenities reveals an overall 13 percent smaller return to education. The parameter estimates of Column (4) are in close accord with the 16 percent return to education per additional year of schooling completed reported by Ashenfelter and Krueger (1994).

An interesting impact of the introduction of independent control variables for amenities in the earnings function is seen when looking at the Union variable. Unions may have been receiving credit for wage gains that are in large part due to local disamenities in areas of union strength. In comparing coefficients across Columns (1)-(4), wage compensation for amenities is mostly responsible although regional affects also contribute. Overall, holding wage compensation for amenities and regional effects constant, the impact of unions on earnings is revealed to be 26 percent smaller than in traditional specifications.

Controlling for regional effects, but not amenity wage compensation, reveals a larger positive impact of experience than that in the traditional specification. At the mean for experience in the data (9.965), the impact of one additional year of experience is $.0019, .0018, .0068$, and .0067 moving from Column (1)-(4). The maximum return to experience (from Column (4) rather than Column (3) because of the smaller negative quadratic coefficient) occurs with 13.72 years of experience vis-á-vis the 11.28 found for the traditional specification.

Other effects of regional and amenity wage compensation are minor - reduced (insignificant) negative impact of race, reduced positive impact of marriage by 10 percent, lowered impact of occupation (except for wholesale and retail trade which is revealed to have a more pronounced negative effect on earnings), and halved (insignificant) impact of population size. Relative to the omitted North Central, all other regions receive lower earnings, likely reflecting greater amenity levels, while direct amenity wage compensation is significantly negative as expected. $F$-tests indicate that the wage compensation variable and the regional dummies are, separately and collectively, statistically significant.

Columns (5) and (6) of Table 2 present results for the specification in which the earnings variable is adjusted for wage compensation, purging amenity variation through the dependent variable rather than holding amenities constant on the right-hand side. Since the wage compensation variable has a large standard deviation this approach results in much greater variance to be explained, hence the lower $R^{2}$.

Results are even more striking, and quite consistent with those discussed above, for the adjusted dependent variable case. Returns to education are 20 percent (23 percent when regional effects are controlled) lower than one would expect based on the traditional specification. The finding that returns to union membership are overstated in 
the traditional model is even stronger in this approach: The coefficient on this variable is seen to be only 46-50 percent as large as in Column (1), depending on whether or not regional dummies are included. The negative impact of the West dummy becomes significant and larger, comparing Columns (6) and (4). Other coefficients in Columns (5) and (6) appear somewhat smaller than their counterparts (Columns (2) and (4)) but possess similar implications when compared to the traditional model of Column (1).

\section{Conclusions}

Our central finding is that traditional labor earnings equations are very likely to exhibit omitted-variable bias. Our important findings are that the returns to both union membership and education are substantially overstated by failing to control for amenity wage compensation (by as much as 50 percent and 20 percent, respectively). The nature of the bias will generally depend on the included subset of possible locations underlying the observations. If (as is the case here) the units of observation come from predominantly large urban concentrations of a productive nature, the returns to education are likely to be biased upward by failing to control for amenities. Though less likely as a practical matter, if a data set comprised of desirable but not overly productive (typically smaller) locations were employed to estimate earnings functions, the return to education would be biased downward by failure to control for amenity wage compensation.

The problem of omitted-variable bias is, interestingly, not eliminated by avoiding national data sets and considering only data points entirely contained within one labor market. There is a sense in which amenities are "held constant" by this approach, but heterogeneity of preferences for amenities continues to plague analysis. Consider the study of the returns to education in a desirable labor market, say Malibu or Aspen. The influx of high-income (and well-educated) individuals drives down their wages relative to elsewhere while rents are being substantially driven up (Figure 1a). At the same time, the rents (or commuting costs) facing the low-wage (and education) individuals in such areas will be higher than their value of the amenities - hence higher wages will be paid to this group in equilibrium. ${ }^{6}$ The narrowing of the wage gap for given differences in educational attainment results in a downward bias to the observed return to education. Similarly, an undesirable area, say Gary or Detroit, will yield higher wages and lower rents for the highly educated, with the lower rents causing those with lower education to require less wage compensation than they would receive in nicer areas. Hence, the "spread" in wages resulting from a given difference in education becomes larger and returns to education are biased upward, even though amenities are nominally held constant by considering only observations with similar amenity levels. 


\section{NOTES}

${ }^{1}$ Exceptions typically involve inclusion of regional dummy variables, though in many contexts their interpretation focuses on the speed of adjustment to an assumed disequilibrium, (e.g., the North-South wage equalization issue emphasized in Coehlo and Ghali $(1971,1973)$ and Sahling and Smith (1983). Coehlo and Ghali (p. 937) conclude that "The North-South differential in real wage, however, was found to be insignificantly different from zero." Note that if the South has a better household amenity bundle, the absence of a differential in "real" wage as measured would indicate that real wages are actually higher in the South (plausible in light of the substantial in-migration observed over the post-1973 period). The only other analysis that is similar in spirit to that presented here is the fine recent contribution of Beeson (1991). Her emphasis is on a detailed examination of the impact of her choice of amenities on the returns to education.

${ }^{2} \mathrm{BBH}$ combined sixteen amenity value estimates to calculate an aggregate amenity value, broken into wage and rent compensation components, for large counties in 1980. The reliability of the wage and rent compensation, for the larger counties, was enhanced by the use of 34,414 households and 46,004 workers. We thank Glenn Blomquist for providing these data.

${ }^{3}$ The sources are The 1983 City and County Data Book, General Social \& Economic Characteristics, General Population Characteristics, Union Membership in the United States: 1973-1981 (Kokkelenberg and Sockell, 1985).

${ }^{4}$ As Berndt (1990, p. 161) observes: "The log-normal distribution is a skewed distribution that fits actual earnings distributions quite well, perhaps better than any other rather simple distribution."

${ }^{5}$ This result is consistent with Beeson's (1991).

${ }^{6}$ The compensation required by the low-wage individuals will depend on whether the excess of market rents over their value of amenities is greater or less than their cost of commuting from a less desirable, but lower rent location. If commuting costs are comparatively low, service workers employed in desirable locations (e.g., maids) will require less wage compensation than would be the case if high commuting costs led them to occupy very expensive rental space.

\section{REFERENCES}

Ashenfelter, Orley and Alan Krueger. "Estimates of the Economic Return to Schooling from a New Sample of Twins." American Economic Review 84 (December 1994):1157-73.

Beeson, Patricia E. “Amenities and Regional Differences in Returns to Worker Characteristics." Journal of Urban Economics 30 (July 1991): 224-41.

Berndt, Ernst. The Practice of Econometrics: Classic and Contemporary: Reading, Penn.: Addison-Wesley, 1991.

Blomquist, Glenn C., Mark C. Berger, and John P. Hoehn. "New Estimates of Quality of Life in Urban Areas." American Economic Review 78 (March 1988): 89-107.

Coehlo, Philip R. and Moheb A. Ghali. "The End of the North-South Wage Differential." American Economic Review 61 (December 1971): 932-37.

"The End of the North-South Wage Differential: Reply." American Economic Review 63 (September 1973): 757-62.

Graves, Philip E. "A Life-Cycle Empirical Analysis of Migration and Climate, by Race." Journal of Urban Economics 6 (April 1979): 135-47.

Haurin, Donald R. "The Regional Distribution of Population, Migration, and Climate." Quarterly Journal of Economics 95 (September 1980): 293-308. 
Kokkelenberg, Edward C. and Donna R. Sockell. "Union Membership in the United States: 1973-1981." Industrial and Labor Relations Review 38 (July 1985): 497-543.

Roback, Jennifer. "Wages, Rents, and Amenities: Differences among Workers and Regions." Economic Inquiry 26 (January 1988): 23-41. $1257-78$.

"Wages, Rents, and the Quality of Life." Journal of Political Economy 90 (December 1982):

Rosen, Sherwin. "Wage-Based Indexes of Urban Quality of Life." In Current Issues in Urban Economics, Peter Mieszkowski and Mahlon Straszheim, eds. Baltimore: John Hopkins University Press, 1979.

Sahling, Leonard G. and Sharon P. Smith. "Regional Wage Differentials: Has the South Risen Again?" Review of Economics and Statistics 65 (May 1983): 131-35. 